\title{
Influence of heavy metals on bromoxynil decay in soil from Legnica-Głogów Copper District
}

\section{Wpływ metali ciężkich na rozkład bromoksynilu w glebie z Legnicko-Głogowskiego Okręgu Miedziowego}

\author{
Olga Kalitowska*, Mariusz Kucharski
}

\begin{abstract}
Summary
The aim of the studies was to determine the influence of heavy metals on bromoxynil degradation in soil. The experiments were carried out under laboratory conditions (plant growth chamber). Bromoxynil was applied to two different soils, which have similar textures, $\mathrm{pH}$ and organic carbon content but differed in the content of copper, lead and zinc. The soil sample that originated from Copper District was contaminated with heavy metals while another sample represented soil with low heavy metals concentration. The soil samples were taken for analyses 1 hour (initial concentration) and 2, 4, 8, 16, 32 and 64 days after treatment. Bromoxynil residue was analysed using GC/ECD (gas chromatography with electron capture detector). The differences in the content of heavy metals affected the bromoxynil decay in soil. A high concentration of heavy metals in soil slowed down of bromoxynil degradation only in the first 2 weeks after herbicide application. After this period degradation of bromoxynil in the both soils was similar and differences between values of $\mathrm{DT}_{50}$ were not significant. The values of $\mathrm{DT}_{50}$ obtained in the experiment varied from 27 to 29 days. Moreover, the application of herbicide caused short-term decrease in microbiological activity of the soils, especially in the soil contaminated with heavy metals.
\end{abstract}

Key words: bromoxynil; heavy metals; degradation; soil; $\mathrm{DT}_{50}$

\section{Streszczenie}

Celem pracy była ocena wpływu metali ciężkich na rozkład bromoksynilu w glebie. Doświadczenia prowadzono w warunkach kontrolowanych (komora klimatyczna). Bromoksynil aplikowano na dwie gleby o zbliżonym składzie granulometrycznym, pH i zawartości węgla organicznego, a o zróżnicowanej zawartości metali ciężkich: gleba skażona metalami ciężkimi z okolic huty miedzi $(\mathrm{Cu}, \mathrm{Pb}, \mathrm{Zn})$ i gleba o niskiej, naturalnej zawartości tych metali. Próbki gleby do analiz pobierano 1 godzinę po opryskiwaniu (stężenie początkowe), a następne po $2,4,8,16,32$ i 64 dniach po aplikacji herbicydu. Pozostałości bromoksynilu oznaczano metodą chromatografii gazowej z detektorem wychwytu elektronów (GC/ECD - gas chromatography with electron capture detector). Zawartość metali ciężkich w glebie miała wpływ na przebieg rozkładu. Wolniejszy rozkład bromoksynilu w okresie pierwszych 2 tygodni po zabiegu stwierdzono w glebie zanieczyszczonej metalami ciężkimi. Po tym okresie rozkład w obu glebach był zbliżony, a uzyskane czasy połowicznego rozkładu $\mathrm{DT}_{50}$ nie różniły się znacząco i wynosiły $27-29$ dni. Ponadto stwierdzono, że aplikacja bromoksynilu spowodowała przejściowe zahamowanie aktywności mikrobiologicznej gleb, które było szczególnie widoczne w glebie skażonej metalami.

Słowa kluczowe: bromoksynil; metale ciężkie; rozkład; gleba; $\mathrm{DT}_{50}$

\footnotetext{
Instytut Uprawy Nawożenia i Gleboznawstwa - Państwowy Instytut Badawczy

Zakład Herbologii i Technik Uprawy Roli

Orzechowa 61, 50-540 Wrocław

*corresponding author: o.kalitowska@iung.wroclaw.pl
} 


\section{Wstęp / Introduction}

Huta Miedzi Głogów II, wchodząca w skład Kombinatu Górniczo-Hutniczego Miedź Polska S.A., jest źródłem zanieczyszczenia gleb metalami ciężkimi, w szczególności miedzią, ołowiem i cynkiem (Rosada 2007; Jaworska i Dąbkowska-Naskręt 2012). Bezpośrednie sąsiedztwo huty $\mathrm{z}$ gruntami ornymi ma wpływ na strukturę ich użytkowania. Jednym z kierunków zagospodarowania tych terenów jest uprawa roślin przemysłowych i energetycznych (Strączyński i Strączyńska 2009; Kabała i wsp. 2010). W Polsce dokumentem regulującym dopuszczalne zawartości metali ciężkich w gruntach ornych jest Rozporządzenie Ministra Środowiska w sprawie standardów jakości gleb oraz standardów jakości ziemi (Rozporządzenie 2002). Nawet niewiele podwyższone zawartości miedzi i cynku w gruntach ornych mogą realnie wpływać na tempo oraz drogi degradacji stosowanych środków ochrony roślin (Said i Lewis 1991; Lock i Janssen 2005; Klimek i Niklińska 2007).

Bromoksynil (3,5-dibromo-4-hydroksybenzonitryl) jest substancją czynną dostępną na rynku w wielu preparatach stosowanych do powschodowego zwalczania chwastów w uprawach kukurydzy. Bromoksynil jest podatny na fotolizę ze względu na swoje podstawienie hydroksylowe (Millet i wsp. 1998; Chelme-Ayala i wsp. 2010). Największe znaczenie przy degradacji tej substancji ma jednak rozkład mikrobiologiczny. Dane literaturowe jednoznacznie wskazują, iż metale ciężkie mają wpływ na aktywność enzymatyczną grzybów i bakterii. W małych stężeniach metale mogą działać stymulująco, w dużych wykazują działanie hamujące (Nowak i wsp. 1999; Mocek-Płóciniak 2011). W swoich badaniach Giller i wsp. (2009) sugerują, iż reakcja mikroorganizmów na stres związany $\mathrm{z}$ obecnością metali ciężkich w glebie może być nieprzewidywalna i w znacznym stopniu może zależeć od stanu gleby przed skażeniem. Szczególne znaczenie przy ocenie wpływu metali ciężkich na aktywność mikrobiologiczną gleb ma oznaczenie aktywności dehydrogenaz. Jest to bowiem wskaźnik intensywności metabolizmu oddechowego bakterii i promieniowców, szczególnie wrażliwy na działanie metali ciężkich (Margesin i wsp. 2000; Mocek-Płóciniak 2011).

Celem pracy była ocena wpływu metali ciężkich $(\mathrm{Cu}$, $\mathrm{Zn}, \mathrm{Pb}$ ) na rozkład bromoksynilu w glebie.

\section{Materiały i metody / Materials and methods}

Doświadczenia prowadzono w warunkach kontrolowanych. Gleby do badań pobrano $\mathrm{z}$ pól uprawnych z warstwy ornej 0-20 cm. W doświadczeniu wykorzystano dwie gleby o znacząco zróżnicowanej zawartości metali ciężkich. Jedna z gleb (G1) o zwiększonej zawartości metali, pochodziła $\mathrm{z}$ miejscowości Żukowice, z obszaru będącego w zasięgu oddziaływania Huty Miedzi Głogów II, druga (G2), charakteryzująca się brakiem tych zanieczyszczeń, została pobrana z pola uprawnego w Okulicach. Gleby dobrano tak, by ich podstawowe parametry ( $\mathrm{pH}$, skład granulometryczny, zawartość $\mathrm{C}_{\mathrm{org}}$ ) były zbliżone, co pozwoliło ograniczyć wpływ właściwości gleby na rozkład bromoksynilu. Doświadczenie założono w 3 powtórzeniach dla każdego $\mathrm{z}$ wariantów gleby. Badania fizykochemiczne gleb przeprowadzono w Zakładzie Herbologii i Technik Uprawy Roli we Wrocławiu. Skład granulometryczny oznaczono metodą Casagradne w modyfikacji Prószyńskiego, $\mathrm{pH}$ ustalono metodą potencjometryczną, zawartość $\mathrm{C}_{\text {org }}$ oznaczono metodą Tiurina, zawartość przyswajalnych form $\mathrm{Cu}, \mathrm{Pb}$ i $\mathrm{Zn}$ określono metodą absorpcyjnej spektrofotometrii atomowej (AAS Atomic Absorption Spectrometry) (Karczewska i Kabała 2008). Właściwości fizykochemiczne gleb przedstawiono w tabeli 1.

Glebą o ustalonej wilgotności napełniano doniczki (300 g gleby na doniczkę). Bromoksynil aplikowano na glebę $\mathrm{w}$ formie herbicydu Emblem 20 WP w dawce $2 \mathrm{~kg} / \mathrm{ha}$, w stacjonarnej komorze opryskowej wyposażonej w ruchomą dyszę typu TeeJet XR 11003-VS, umożliwiającą wydajność cieczy użytkowej równą 250 1/ha przy ciśnieniu roboczym $0,25 \mathrm{MPa}$. Po aplikacji herbicydu doniczki z glebą umieszczono w komorze klimatycznej (Sanyo MLR-350), w której utrzymywano stałe parametry (temperatury i oświetlenie) imitujące warunki w czasie wiosennej aplikacji herbicydu (dzień - 16 godz., temperatura $20^{\circ} \mathrm{C}$, natężenie światła 14000 luxów; noc -8 godz., $10^{\circ} \mathrm{C}$, bez oświetlenia). Wilgotność gleb utrzymywano na stałym poziomie (60\% maksymalnej pojemności wodnej) przez cały czas trwania badań (metodą wagową). Próbki gleb do oznaczania zawartości bromoksynilu pobierano 2 godziny po aplikacji herbicydu (stężenie początkowe) oraz 2, 4, 8, 16, 32 i 64 dni po zabiegu (Sadowski i wsp. 2013). Procedura przygotowania próbek glebowych do oznaczenia aktywności mikrobiologicznej, zastosowana dawka herbicydu oraz warunki inkubacji były identyczne, jak w przypadku doświadczeń z wpływem metali ciężkich na degradację bromoksynilu. Próbki do analiz dehydrogenazy pobierano $8 \mathrm{~h}$ po wykonaniu zabiegu, a następnie po 1, 3, 7 i 10 dniach od aplikacji herbicydu.

Ekstrakcję pozostałości bromoksynilu z materiału glebowego prowadzono na aparacie Dionex 350 AS w cyklu z dwukrotną ekstrakcją acetonem w temperaturze $40^{\circ} \mathrm{C}$, przy ciśnieniu $0,2 \mathrm{MPa}$. Powstały, oczyszczony ekstrakt o objętości $33 \mathrm{ml}$, odparowano na próżniowej wyparce rotacyjnej (temp. $40^{\circ} \mathrm{C}, 90 \mathrm{obr} / \mathrm{min}$ ). Suchą pozostałość rozpuszczono $\mathrm{w} 10 \mathrm{ml}$ acetonu. $\mathrm{Z}$ powstałego roztworu pobrano $2 \mathrm{ml} \mathrm{i}$ poddano procesowi derywatyzacji. Przeprowadzenie w pochodną miało na celu poprawę lotności oznaczanej substancji i zostało wykonane przy użyciu $2 \mathrm{ml}$ diazometanu rozpuszczonego w eterze. Otrzymaną pochodną był metoksybromoksynil. Pochodną bromoksynilu oznaczono na chromatografie gazowym Varian CP-3800 z detektorem wychwytu elektronów wyposażonym $\mathrm{w}$ kolumnę kapilarną VF-5ms $(30 \mathrm{~m} \times 0,25 \mathrm{~mm})$. Gazem nośnym był azot, którego przepływ ustawiono na $1,5 \mathrm{ml} / \mathrm{min}$. Temperaturę pieca kolumny zaprogramowano w następującym cyklu: temperatura początkowa $120^{\circ} \mathrm{C}$ przez $7 \mathrm{~min}$. Następnie wzrost temperatury z szybkością $10^{\circ} \mathrm{C} / \mathrm{min}$. do $200^{\circ} \mathrm{C}$ i utrzymanie jej przez $2 \mathrm{~min}$. Ponowny wzrost $\mathrm{z}$ prędkością $5^{\circ} \mathrm{C} / \mathrm{min}$. do uzyskania temperatury $230^{\circ} \mathrm{C}$, którą utrzymywano przez $20 \mathrm{~min}$. Temperaturę komory nastrzykowej i detektora ustawiono odpowiednio na $230 \mathrm{i} 300^{\circ} \mathrm{C}$. 
Tabela 1. Charakterystyka gleb

Table 1. Soil characteristics

\begin{tabular}{|c|c|c|c|c|c|c|c|c|}
\hline \multirow[b]{2}{*}{$\begin{array}{l}\text { Gleba } \\
\text { Soil }\end{array}$} & \multicolumn{3}{|c|}{$\begin{array}{c}\text { Skład granulometryczny } \\
\text { Granulometric composition }\end{array}$} & \multirow{2}{*}{$\begin{array}{c}\mathrm{pH} \\
{[1 \mathrm{M} \mathrm{KCl}]}\end{array}$} & \multirow{2}{*}{$\begin{array}{l}\mathrm{C}_{\mathrm{org}} \\
{[\%]}\end{array}$} & \multirow{2}{*}{$\begin{array}{c}\mathrm{Cu} \\
{[\mathrm{mg} / \mathrm{kg}]}\end{array}$} & \multirow{2}{*}{$\begin{array}{c}\mathrm{Zn} \\
{[\mathrm{mg} / \mathrm{kg}]}\end{array}$} & \multirow[b]{2}{*}{$\begin{array}{c}\mathrm{Pb} \\
{[\mathrm{mg} / \mathrm{kg}]}\end{array}$} \\
\hline & $\begin{array}{c}\text { piasek } \\
\text { sand } \\
{[\%]}\end{array}$ & $\begin{array}{c}\text { pył } \\
\text { silt } \\
{[\%]}\end{array}$ & $\begin{array}{c}\text { ił } \\
\text { clay } \\
{[\%]}\end{array}$ & & & & & \\
\hline G1 & 30 & 64 & 6 & 7,3 & 1,23 & 380 & 192 & 157 \\
\hline G2 & 36 & 62 & 2 & 7,1 & 1,21 & 3,7 & 2,3 & 32 \\
\hline
\end{tabular}

Wartości podstawowych parametrów charakteryzujących metodę analityczną mieściły się w granicach akceptowalnych, wyznaczonych dla tego typu analiz (SANCO 2013) (oznaczalność 0,001 mg/kg, powtarzalność 5,6\%, średni odzysk 98,7\%).

Dehydrogenazy oznaczano w świeżym materiale glebowym, metodą kolorymetryczną według metodyki Thalmann (1968) oraz Zabłockiej-Godlewskiej i wsp. (1999). Aktywność dehydrogenazy wyrażono w mg powstałego w glebie formazanu.

Wymagane obliczenia statystyczne wykonano w programie ARM 8. Wartości obliczonych odchyleń standardowych przedstawiono graficznie na wykresie (rys. 1, 2). Do opisu rozkładu chlorotoluronu w glebie zastosowano model oparty o równanie kinetycznej reakcji pierwszego rzędu.

\section{Wyniki i dyskusja / Results and discussion}

Rozkład bromoksynilu w glebie G1 i G2 przedstawiono na rysunku 1. Stężenie początkowe bromoksynilu we wszystkich badanych próbkach gleby wynosiło $0,832 \pm 0,0426 \mathrm{mg} / \mathrm{kg}$. Największe zróżnicowanie w szybkości degradacji bromoksynilu obserwowano w pierwszych dniach trwania doświadczenia. Spowolnienie rozkładu w glebie skażonej metalami ciężkimi (G1) było znaczące i w 8. dniu po aplikacji herbicydu w glebie G1 zostało rozłożone 24\%, natomiast w glebie G2 39\% zaaplikowanej dawki bromoksynilu. Między 16. a 64. dniem trwania doświadczenia nie obserwowano istotnych różnic w szybkości degradacji badanego związku. Na podstawie

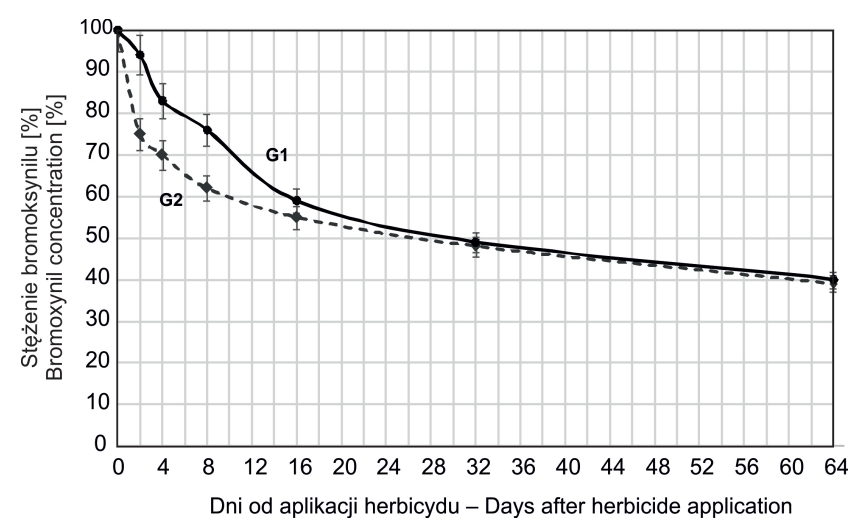

Rys. 1. Rozkład bromoksynilu w glebach

Fig. 1. Bromoxynil decomposition in soils uzyskanych wyników można stwierdzić, że rozkład bromoksynilu w badanych glebach został znacząco zahamowany po 16 dniach od rozpoczęcia eksperymentu.

Początkowo znacznie wolniejszy rozkład bromoksynilu w glebie G1 nie przełożył się na wyższą wartość czasu połowicznego rozkładu. Rozpatrując przebieg rozkładu bromoksynilu można stwierdzić, że ze względu na uzyskane czasy połowicznego rozkładu $\left(\mathrm{DT}_{50}\right)$, nie odnotowano wpływu obecności metali ciężkich na szybkość jego degradacji (wartości $\mathrm{DT}_{50}$ dla obu gleb były zbliżone). Dodatkowo wyznaczone krzywe rozkładu opisano matematycznie. Najlepsze dopasowanie danych eksperymentalnych do modelu uzyskano stosując równanie funkcji wykładniczej (kinetyczne równanie reakcji pierwszego rzędu). Taki wybór modelu przebiegu rozkładu opisują również inni autorzy (Ravelli i wsp. 1997; Cuevas i wsp. 2007). W przypadku przeprowadzonego testu dopasowanie danych eksperymentalnych do tego równania było wystarczające. Współczynnik korelacji $\mathrm{r}^{2}$ zawierał się $\mathrm{w}$ przedziale 0,94-0,97 (tab. 2). Zgodnie z przyjętymi zasadami (Guidance 2000) dopasowanie danych eksperymentalnych do równania można uznać za prawidłowe, jeżeli współczynnik korelacji jest równy lub wyższy niż 0,7 . Na podstawie równań opisujących krzywe wyliczono wartości czasu połowicznego rozkładu $\left(\mathrm{DT}_{50}\right)$ bromoksynilu w glebach. Uzyskane wyniki były zbliżone do wartości odczytanych z wykresu, co potwierdziło brak większych różnic w wartościach $\mathrm{DT}_{50}$ dla obu gleb (tab. 2). Jednak biorąc pod uwagę pierwsze dwa tygodnie od aplikacji herbicydu można stwierdzić, że obecność metali spowolniła rozkład, co może przekładać się na wyższą skuteczność środka w zwalczaniu chwastów, gdyż to właśnie w tym okresie aktywność i skuteczność preparatu jest najwyższa. Zróżnicowany wpływ metali ciężkich na rozkład herbicydów w glebie jest również sygnalizowany przez innych autorów (Suhadolc i wsp. 2004; Sadowski i wsp. 2013). Często odmienne obserwacje świadczą o tym, że nie można wyciągnąć jednego, uniwersalnego wniosku, który charakteryzowałby zachowanie herbicydów w glebie skażonej metalami ciężkimi. Omawiany wpływ uzależniony jest również od innych czynników, jak rodzaj substancji czynnej, typ gleby, wielkość skażenia, czy obecność innych ksenobiotyków. Bromoksynil jest substancją dobrze rozpuszczalną $\mathrm{w}$ wodzie i szybko zanikającą w glebie (Millet i wsp. 1998). W glebach lekkich, piaszczystych czas połowicznego rozkładu wynosi ok. 10 dni, w glebach cięższych, bogatych we frakcję ilastą czas ten jest dłuższy i wynosi ok. 14 dni (Pampulha i Oliveira 
Tabela 2. Równania krzywych rozkładu bromoksynilu w glebach oraz wartości $\mathrm{DT}_{50}$

Table 2. Equations for bromoxynil degradation curves and values of $\mathrm{DT}_{50}$

\begin{tabular}{|c|c|c|c|c|}
\hline \multirow[b]{2}{*}{$\begin{array}{c}\text { Gleba } \\
\text { Soil }\end{array}$} & \multirow{2}{*}{$\begin{array}{l}\text { Równanie krzywej rozkładu } \\
\text { (dla wartości średnich) } \\
\text { Equation of degradation curve } \\
\text { (for average values) }\end{array}$} & \multirow{2}{*}{$\begin{array}{l}\text { Współczynnik } \\
\text { korelacji } \\
\text { Correlation } \\
\text { coefficient }\end{array}$} & \multicolumn{2}{|c|}{$\mathrm{DT}_{50}[$ dni - days $]$} \\
\hline & & & $\begin{array}{l}\text { wyznaczone graficznie } \\
\text { graphically } \\
\text { determined }\end{array}$ & $\begin{array}{c}\text { wyliczone } \mathrm{z} \text { równania } \\
\text { calculated } \\
\text { from equation }\end{array}$ \\
\hline G1 & $\mathrm{C}_{\mathrm{t}}=0,853 \times \mathrm{e}^{-0,0210 \mathrm{t}}$ & $r^{2}=0,9723$ & $28,8 \pm 1,34$ & 32,7 \\
\hline G2 & $\mathrm{C}_{\mathrm{t}}=0,936 \times \mathrm{e}^{-0,0231 \mathrm{t}}$ & $r^{2}=0,9468$ & $27,4 \pm 1,26$ & 30,2 \\
\hline
\end{tabular}

$\mathrm{C}_{\mathrm{t}}$ - stężenie bromoksynilu po czasie ,„t" - bromoxynil concentration at time “ $\mathrm{t}$ ”

2006). Inne źródła podają wartości $\mathrm{DT}_{50}$ dla bromoksynilu w granicach 3-5 dni (Chen i wsp. 2011). Uzyskane z danych eksperymentalnych wartości DT $_{50}$ (ok. 30 dni) wskazują na to, iż na wolniejszy rozkład tej substancji ma wpływ istotnie wyższe $\mathrm{pH}$ gleby. Prace innych autorów dowodzą, iż rozkład bromoksynilu na glebach o wyższym odczynie jest znacznie wolniejszy, może być wręcz zahamowany (Sheng i wsp. 2005; Pampulha i Oliveira 2006; Morimoto i Shimmen 2008; Chen i wsp. 2011). Bromoksynil jest łatwo rozkładany w glebie za pośrednictwem enzymów produkowanych przez mikroorganizmy. Jego rozpad zostaje przyspieszony po dostarczeniu do gleby źródła łatwo przyswajalnego węgla. Nasuwa to przypuszczenie, że pierwszym etapem degradacji bromoksynilu może być kometabolizm, który zależy od obecności odpowiednich substratów (Rosenbrock i wsp. 2004; Holze i wsp. 2008). Oznaczono również produkcję dehydrogenazy po aplikacji herbicydu na glebę G1 i G2. Uzyskane wyniki przedstawiono na rysunku 2. Można stwierdzić, że dodatek bromoksynilu powodował zmniejszenie aktywności mikrobiologicznej gleby, co przełożyło

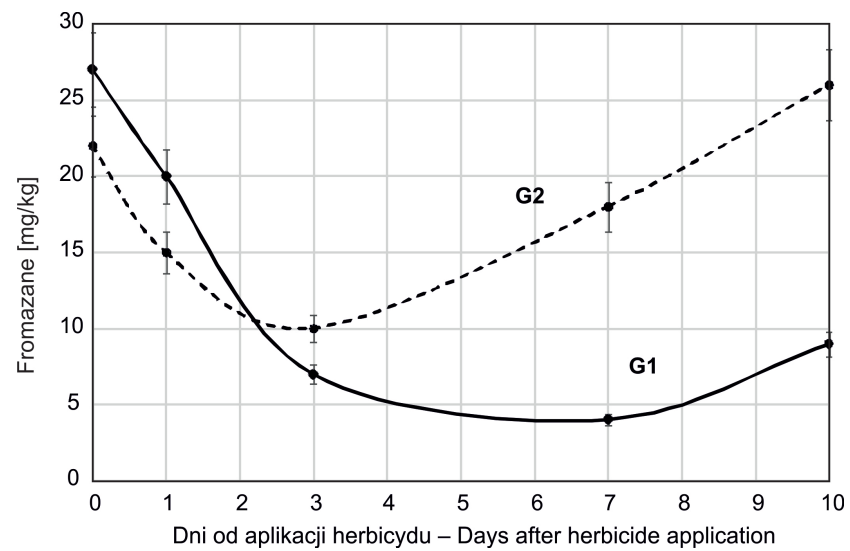

Rys. 2. Zmiany aktywności mikrobiologicznej w glebach po aplikacji bromoksynilu

Fig. 2. Changes of microbial activity in soils after bromoxynil application się na ilość produkowanych dehydrogenaz. Ujemny wpływ aplikacji bromoksynilu był zwłaszcza widoczny w glebie G1 zanieczyszczonej metalami ciężkimi. Wyniki badania aktywności mikrobiologicznej są zbieżne z przebiegiem rozkładu bromoksynilu w glebie i potwierdzają dane literaturowe, w których określa się, że obecność i aktywność mikroorganizmów jest głównym czynnikiem decydującym o szybkości rozkładu tego związku (Rosenbrock i wsp. 2004; Pampulha i Oliveira 2006; Holze i wsp. 2008).

\section{Wnioski / Conclusions}

1. Bromoksynil jest herbicydem o średniej trwałości w glebie. Jego czas połowicznego rozkładu, w warunkach prowadzenia doświadczenia wyniósł 27-29 dni.

2. W pierwszych dwóch tygodniach prowadzenia doświadczenia obserwowano spowolnienie rozkładu bromoksynilu w glebie skażonej emisjami z przemysłu miedziowego. Po 16 dniach obecność metali ciężkich nie różnicowała znacząco rozkładu tego herbicydu. Nie odnotowano również znaczących różnic $\mathrm{w}$ wartościach $\mathrm{DT}_{50}$.

3. Aplikacja bromoksynilu powodowała zmniejszenie aktywności mikrobiologicznej gleby. W przypadku gleby skażonej metalami ciężkimi ograniczenie aktywności mikroorganizmów było silniejsze i trwało powyżej 10 dni, co przyczyniło się do obserwowanego spowolnienia rozkładu bromoksynilu w pierwszych dniach prowadzenia eksperymentu.

\section{Podziękowanie / Acknowledgements}

Praca wykonana w ramach Zadania 1.2 Programu Wieloletniego Instytutu Uprawy Nawożenia i Gleboznawstwa - Państwowego Instytutu Badawczego, finansowanego przez Ministerstwo Rolnictwa i Rozwoju Wsi.

\section{Literatura / References}

Chelme Ayala P., E1 Din M.G., Smith D.W. 2010. Degradation of bromoxynil and trifluralin in natural water by direct photolysis and UV plus $\mathrm{H} 2 \mathrm{O} 2$ advanced oxidation process. Water Research 44 (7): 2221-2228.

Chen X., Li W., Wu Q., Zhi Y., Han L. 2011. Bromoxynil residues and dissipation rates in maize crops and soil. Ecotoxicology and Environmental Safety 74 (6): 1659-1663.

Cuevas M.V., Cox L., Calderon M.J., Hermosin M.C., Fernandez J.E. 2007. Chloridazon and lenacil dissipation in a clayey soil of the Guadalquivir river marshes (southwest Spain). Agriculture, Ecosystems and Environment 124 (3-4): 245-251. 
Giller K.E., Witter E., McGrath S.P. 2009. Heavy metals and soil microbes. Soil Biology \& Biochemistry 41: $2031-2037$.

Guidance Document on Persistence in Soil. 2000. 9188/VI/97 rev. 8, 12.07.2000. European Commission, Directorate General for Agriculture, VI B II.1.

Holze M.S., Sørensen S.R., Sørensen J., Aamand J. 2008. Microbial degradation of the benzonitrile herbicides dichlorobenil, bromoxynil and ioxynil in soil and subsurface environments insights into degradation pathways, persistent metabolites and involved degrader organisms. Environmental Pollution 154 (2): 155-168.

Jaworska H., Dąbkowska-Naskręt D. 2012. Influence of Głogów Copper Works on the content of mobile forms of copper and zinc in arable soils. Journal of Elementology 17 (1): 57-66.

Kabała C., Karczewska A., Kozak M. 2010. Przydatność roślin energetycznych do zagospodarowania gleb zdegradowanych. Zeszyty Naukowe Uniwersytetu Przyrodniczego we Wrocławiu, Rolnictwo 576, XCVI: 97-118.

Karczewska A., Kabała C. 2008. Metodyka analiz laboratoryjnych gleb i roślin. Uniwersytet Przyrodniczy we Wrocławiu, Instytut Nauk o Glebie i Ochrony Środowiska, Zakład Ochrony Środowiska, Wydanie 4. http://www.ar.wroc.pl/ kabala [dostęp: 27.09.2016].

Klimek B., Niklińska M. 2007. Zinc and copper toxicity to soil bacteria and fungi from zinc polluted and unpolluted soils: a comparative study with different type of biology plates. Bulletin Environmental Contamination and Toxicology 78 (2): 112-117.

Lock K., Janssen C.R. 2005. Influence of soil zinc concentration on zinc sensitivity and functional diversity of microbial communities. Environmental Pollution 136 (2): 275-281.

Margesin R., Walder G., Schinner F. 2000. The impact of hydrocarbon remediation (diesel oil and polycyclic aromatic hydrocarbons) on enzyme activities and microbes properties of soil. Acta Biotechnologica 20 (3-4): 313-333.

Millet M., Palm W.-U., Zetzsch C. 1998. Abiotic degradation of halobenzonitriles: Investigation of the photolysis in solution. Ecotoxicology and Environmental Safety 41 (1): 44-50.

Mocek-Płóciniak A. 2011. Wpływ metali ciężkich na mikroorganizmy oraz aktywność enzymatyczną gleby. Roczniki Gleboznawcze 62 (4): 211-220.

Morimoto H., Shimmen T. 2008. Primary effect of bromoxynil to induce plant cell death may by cytosol acidification. Journal of Plant Research 121 (2): 227-233.

Nowak J., Niedźwiedzki E., Dziel M. 1999. Wpływ metali ciężkich na zmiany aktywności enzymatycznej gleby. Roczniki Gleboznawcze 50 (1-2): 61-68.

Pampulha M.E., Oliveira A. 2006. Impact of an herbicide combination of bromoxynil and protosulfuron on soil microorganism. Current Microbiology 53 (3): 238-243.

Ravelli A., Pantani O., Calamai L., Fust P. 1997. Rates of chlorsulfuron degradation in three Brazilian oxisoils. Weed Research 37: 51-59.

Rosada J. 2007. Ekologiczne aspekty wykorzystania obszarów objętych oddziaływaniem emisji hut miedzi do upraw rolniczych. [Ecological aspects of utilizing areas influenced by copper foundries for cultivation of agricultural plants]. Progress in Plant Protection/Postępy w Ochronie Roślin 47 (1): 119-127.

Rosenbrock P., Munch J.C., Scheunert I., Dörfler U. 2004. Biodegradation of the herbicide bromoxynil and its plant cell wall bound residues in an agricultural soil. Pesticide Biochemistry and Physiology 78 (1): 49-57.

Rozporządzenie Ministra Środowiska 2002 w sprawie standardów jakości gleby oraz standardów jakości ziemi. Dz. U. Nr 165 z dnia 4 października $2002 \mathrm{r}$.

Sadowski J., Kucharski M., Wróbel S., Kalitowska O. 2013. Wpływ miedzi na rozkład acetochloru w glebie. [Influence of cooper on acetochlor degradation on soil]. Progress in Plant Protection/Postępy w Ochronie Roślin 53 (4): 674-676.

Said W.A., Lewis D. 1991. Quantitative assessment of the effect of metals on microbial degradation of organic chemicals. Applied and Environmental Microbiology 57 (5): 1498-1503.

SANCO 2013. Document SANCO/12571/2013. Guidance document on analytical quality control and validation procedures for pesticide residues analysis in food and feed, $42 \mathrm{pp}$.

Sheng G., Yang Y., Huang M., Yang K. 2005. Influence of $\mathrm{pH}$ on pesticide sorption by soil containing wheat residue-derived char. Environmental Pollution 134 (3): 457-463.

Strączyński S.J., Strączyńska S. 2009. Bioakumulacja miedzi w wybranych gatunkach roślin uprawianych w rejonie zanieczyszczonym przez hutnictwo miedzi. Zeszyty Problemowe Postępów Nauk Rolniczych 541 (2): 409-416.

Suhadolc M., Schroll R., Gattinger M., Schloter M., Munch J.C., Lestan D. 2004. Effects of modified Pb-, Zn-, and Cd- availability on the microbial communities and on the degradation of isoproturon in a heavy metal contaminated soil. Soil Biology and Biochemistry 36 (12): $1943-1954$.

Thalmann A. 1968. Zur Methodik der Bestimmung der Dehydrogenaseaktivität im Boden Mittels Triphenyltetrazoliumchlorid. Landwirtschaftliche Forschung 21 (12): 249-259.

Zabłocka-Godlewska E., Galimska-Stypa R. 1999. Gleba jako środowisko życia mikroorganizmów. Wydawnictwo Politechniki Śląskiej, Gliwice: 202-204. 